\title{
10. Den romanska litteraturforskningens utveckling och inriktning - med särskilt fokus på Göteborgs universitet
}

\section{Elisabeth Tegelberg}

\subsection{Introduktion}

Om man ser närmare på hur den romanska språk- och litteraturforskningen utvecklats vid Sveriges universitet sedan 1945 och om man tar produktionen av doktorsavhandlingar som måttstock för denna utveckling, kan man konstatera en tydlig utveckling från mycket få ämnen med litterär inriktning till ett kontinuerligt ökande inslag av sådana från slutet av 1970-talet och fram till idag (2016). Detta gäller inte minst Göteborgs universitet, där jag själv varit verksam, men också Stockholms universitet och Lunds universitet (bilden är mindre entydig vid Uppsala universitet).

Syftet med denna studie är att analysera litteraturens ökande omfattning i den forskning som bedrivits i de romanska språken, framför allt så som den avspeglas i produktionen av doktorsavhandlingar i dessa språk, med särskilt fokus på Göteborgs universitet och med ett avslutande avsnitt som komparativt belyser motsvarande utveckling vid Stockholms universitet. De år som är mest signifikativa för utvecklingen sträcker sig från 1980-talet och framåt och dessa kommer därför att ägnas särskild uppmärksamhet. Frågor att ställa sig i detta sammanhang är vilka förklaringsgrunder som kan finnas till utvecklingen från språkliga till litterära ämnen i doktorsavhandlingarna och vilka förutsättningar som har funnits för denna utveckling. En annan fråga som jag kommer att beröra, om än perifert, är om man finner liknande ämnesförskjutningar i examensarbeten på grundnivå och samma utveckling från inriktning på språkliga aspekter till litterära i undervisningen i de romanska språken.

Att jag koncentrerar mig på Göteborgs universitet beror inte enbart på mitt eget förflutna som lärare vid detta lärosäte utan också på att jag, förutom de data som återfinns i Swepub, Avhandlingar.se och Libris, har ett omfattande och gediget material till mitt förfogande i form av Bo Lindbergs och Ingemar Nilssons omfattande historik i fem band över Göteborgs högskola 
och universitet (Lindberg \& Nilsson 1996; Nilsson 1996). Detta senare material har möjliggjort för mig att gå vidare till en mer ingående analys av faktorer som kan ha påverkat utvecklingen mot en litterär positionering vid Göteborgs universitet. De romanska språk det är fråga om är de som har varit föremål för doktorsavhandlingar vid Göteborgs universitet och Stockholms universitet. Det gäller i första hand franska, som hittills har varit det största romanska språket vid samtliga lärosäten, i andra hand spanska, som har kommit starkt under senare decennier, i tredje hand italienska, som intar en klart mindre framträdande plats, och i färde hand portugisiska, som endast har varit föremål för doktorsavhandlingar vid Stockholms universitet.

\subsection{Bakgrund}

Om man betraktar doktorsavhandlingar i romanska språk vid Göteborgs universitet i ett historiskt perspektiv, kan man, grovt sett, urskilja fyra olika perioder med avseende på avhandlingarnas ämnesinriktning, nämligen 1891-1945, 1946-1968, 1969-1980 och 1981-2016. Perioden före 1945 är i detta sammanhang av begränsat intresse, eftersom doktorsavhandlingarna då var få och nästan uteslutande koncentrerade till studiet av äldre språkskeden, med inriktning mot filologi och textedition (cf. Carlsson 1976; Sundell 2013 och 2015 beträffande i synnerhet Uppsala universitet). När det gäller de yttre ramarna, kan man konstatera att språkämnena fick lärostolar i romanska språk och germanska språk redan när Göteborgs högskola inrättades 1891 och att den senare lärostolen delades upp på två, en tysk och en engelsk. De moderna språken var alltså redan från början väl företrädda vid högskolan. Gränsöverskridande ämnen mellan de olika språken var inte helt ovanliga i början, t.ex. tyska och franska, och samarbetet mellan högskolan och läroverken var utvecklat (mycket mer än idag) då universitetstjänsterna var försvinnande få och de som disputerade normalt var hänvisade till läroverkslektorat efter disputation.

Ämnet romanska språk var alltså med från starten och dess förste professor var Johan Vising, som 1923 efterträddes av Hilding Kjellman (cf. Söhrman 2013). 1937 blev Karl Michaëlsson professor, efter vad det tycks en framsynt sådan och en uppskattad handledare för ett ganska stort antal avhandlingar, nästan alla med språkvetenskapligt ämne, inte minst dialektforskning. Under hans tid disputerade för övrigt den förste och ende doktoranden 
på ett ämne med litteraturvetenskaplig inriktning. En ny tid, om än inte med litteraturvetenskapliga förtecken, kan sägas ha startat under Hans Nilsson-Ehles tid som professor (1957-1977) då ett synkroniskt studium av de romanska språkens syntax också började ta plats som forskningsområde. Nilsson-Ehle förde särskilt fram italienskan som ämnesområde, vilket bland annat resulterade i ett relativt stort antal licentiatavhandlingar och en doktorsavhandling i italienska. Några litterära avtryck finner vi emellertid inte $\mathrm{i}$ avhandlingarna från hans tid som professor, utan först under hans efterträdares, Gunnar von Proschwitz. Jag återkommer till detta.

Institutionen för romanska språk växte i omfång och betydelse under Nilsson-Ehles tid och även några decennier därefter. Franskan fortsatte att vara det dominerande romanska språket, inom såväl forskning som undervisning. Spanskan växte sig allt starkare från och med mitten av 1960-talet och 1981 utlystes en professur i ämnet, en professur som dock av olika skäl inte fick en innehavare förrän 1993. Spanskans position stärktes genom dess anknytning till Iberoamerikanska institutet, som tidigare var en del av Institutionen för romanska språk och som under sin storhetstid var det största biblioteket i norra Europa med inriktning på Latinamerika. Ämnets position konsoliderades ytterligare under 1970-talet då den stora latinamerikanska invandringen till Göteborg avspeglade sig bland både lärare och studenter. Den första spanska doktorsavhandlingen vid Göteborgs universitet såg dagens ljus 1974 och var inriktad på modern spansk syntax, därefter dröjde det till 1983 innan det var dags för nästa spanska avhandling, denna gång med litterär inriktning. Spanskans förste professor blev Ken Benson (1993), vars avhandling och forskning hade litterär inriktning.

På grundnivån var studerandetillströmningen mycket god i franska och spanska fram till för några år sedan. Värt att notera är att spanskan under 2010-talet har gått fram starkt på universitetets grundnivå, liksom den har gjort i grundskola och på gymnasium, på bekostnad av såväl franska som tyska. Franskan och spanskan vid Göteborgs universitet har dessutom stärkts genom att dessa språk ingått i det internationella ekonomprogrammet och även genom att spanskan under ett antal år hade en tvåårig utbildning $\mathrm{i}$ latinamerikakunskap. Ämnet har dessutom haft många lärare och forskare av latinamerikanskt ursprung, vilket har inneburit en vitalisering och breddning av utbildningsutbudet både inom språk och litteratur. Franskan har 
få infödda lärare, men en bra mix mellan språkligt och litterärt inriktade forskare och lärare. Undervisningen i italienska lades 2013 ned på grund av vikande studerandetillströmning och ämnet har efter 2005 inte haft några disputationer. År 2009 genomfördes en institutionssammanslagning av de moderna språkämnena (svenska undantaget) vid Göteborgs universitet, och det nya, gemensamma namnet blev Institutionen för språk och litteraturer (SPL). Franskan och spanskan är viktiga språk inom den nya institutionen, även om engelskan intar tätpositionen.

\subsection{De litterära avhandlingarnas framväxt och utveckling vid Göteborgs universitet}

Det var först på 1980-talet som det i större skala började skrivas avhandlingar med litterär inriktning inom de romanska språken vid Göteborgs universitet. En faktor av stor vikt i detta sammanhang är de undervisande och handledande lärarnas - i första hand professorers och docenters - forskningsspecialiseringar och vetenskapliga intresseinriktningar, vilka utövat en otvetydig påverkan på de forskarstuderandes val av avhandlingsämne. Ett bra exempel på detta är Gunnar von Proschwitz, som efter en kort sejour $\mathrm{i}$ Uppsala som innehavare av den där nyinrättade professuren i fransk litteraturvetenskap återvände till Göteborg, där han var professor mellan 1977 och 1988. Hans huvudsakliga intresse var 1700-talets Frankrike, vars ord- och brevskatt han behandlade ingående i sin forskning och vars press han också intresserade sig för. Utifrån denna senare intresseinriktning initierade han för sina avhandlingsförfattare ett pressforskningsprojekt med utgångspunkt i 1700-talstidningen Correspondance littéraire secrète, ett projekt som ett antal doktorander anslöt sig till och som resulterade i ett antal disputationer. Även om denna forskning inte kan betecknas som renodlat litteraturvetenskaplig, i ordets allmänt vedertagna mening, måste man ändå säga att den närmare anknyter till franskämnets litterära än dess språkliga sida. Man överdriver därför inte om man säger att dessa avhandlingar innebar ett genombrott för det litteraturvetenskapliga avhandlingsförfattandet i ämnet franska vid Göteborgs universitet.

Det torde vara en blandning av egna intressen, tillgång till eminent handledningsexpertis på området - och kanske även en dragning till "konkreta" ämnen som gav möjlighet att slutföra avhandlingsarbetet inom överskådlig tid 
(vilket inte alltid hade varit fallet tidigare) - som lockade doktoranderna in på detta projekt. Gunnar von Proschwitz hade ambitionen att doktoranderna skulle disputera i rimlig tid och bedrev en målinriktad seminarieverksamhet för att detta mål skulle uppnås. De franska doktoranderna - och disputationerna - ökade kraftigt i antal under hans tid. Till detta bidrog sannolikt också de förbättrade möjligheterna att under dessa år få sina doktorandstudier finansierade genom utbildningsbidrag och doktorandtjänster.

Under 2000-talet kan man konstatera att doktorandernas egna personliga intresseinriktningar på ett tydligare sätt avspeglar sig i valet av avhandlingsämne. Konsekvensen är en ökad bredd i ämnesutbudet och en starkare ställning för litteraturvetenskapliga avhandlingsämnen. Ämnen med feministisk inriktning och med fokus på frankofona författare utanför Frankrike blir t.ex. vanligare (cf. Cedergren 2015; Cedergren \& Lindberg 2017). Friheten att välja ämne förefaller således mer uttalad. Detta är säkerligen inte något som är unikt för de romanska språken eller för Göteborgs universitet utan snarare ett uttryck för den liberalare syn, med mindre fasta gränser och normer, som genomsyrar delar av samhället. Att rekrytera forskarstuderande till de olika språken har blivit allt viktigare och i takt med ökad och breddad rekrytering har också följt en mindre rigid syn på ämnesval för avhandlingarna.

Den verkligt stora vändningen mot det litterära inom franskämnet vid Göteborgs universitet inträffade i början av 2000-talet, inte minst genom Eva Ahlstedt som först som docent och senare som professor i franska rekryterade doktorander med litterära intressen. Hon var mer uttalat litterärt inriktad än sina företrädare som professor, Lars Lindvall och Christina Heldner, båda med primärt språkvetenskaplig intresseinriktning. Inte bara professorernas inställning utan också lektorernas påverkade "kantringen" mot det litterära i franska, något som man finner både inom undervisning och forskning alltsedan slutet av 1990-talet och som man tydligt kan avläsa både i valet av uppsats- och avhandlingsämnen. Detta nya scenario var resultatet av ett målinriktat arbete i syfte att uppmuntra studenterna att göra litterära val, men det är naturligtvis också ett uttryck för att studenternas intressen, av olika skäl, blivit alltmer inriktade på litterära aspekter på bekostnad av språkliga. Utvecklingen mot litteratur är emellertid inte lika påtaglig i spanska där man kan konstatera en större jämvikt mellan språk och litteratur med avseende på avhandlingsproduktion, sannolikt till viss del beroende på att det under 
2000-talet har funnits en docent, senare professor, med språkvetenskaplig meritering och kompetens (Ingmar Söhrman).

En fråga att ställa sig är varför litteraturvetenskapliga ämnen med tiden kommit att spela en större roll i doktorsavhandlingar och examensarbeten. Svarar denna utveckling mot ett "bredare" intresse för litteratur, t.ex. i kulturdebatten? Finns det en mer generell strömning från form mot innehåll, både i språkliga och i andra sammanhang? Kan förskjutningen tänkas spegla en samhällsutveckling mot kommunikation och förståelse för mänskliga bevekelsegrunder och förhållningssätt? Man kan t.ex. fråga sig om traditionella språkvetenskapliga ämnen, som ofta varit inriktade på ett mycket begränsat område, efter hand har kommit att upplevas som alltmer perifera och om en strävan efter förståelse av större sammanhang och existentiella villkor har tagit överhanden. Känns det "litterära" helt enkelt mer angeläget, angår det oss mer än det språkliga? Frågorna är många, men några entydiga svar är inte möjliga att ge med mindre än att man gör intervjuer med berörda personer. Troligt är väl att flera av ovan nämnda faktorer (och även andra) har samverkat och gemensamt givit upphov till den utveckling som vi bevittnat. Av betydelse för utvecklingen i Göteborgs fall är också det faktum att Institutionen för romanska språk inte deltog i den primärt språkvetenskapligt inriktade nationella forskarskolan i romanska språk (FoRom) eller i andra projekt som dragit till sig icke-litterära doktorander, t.ex. inom samtalsforskning (Stockholms universitet) och språkinlärningsforskning (Stockholms universitet och Lunds universitet). Detta torde ha bidragit till det påfallande svaga inslaget av språkliga avhandlingsämnen i franska vid Göteborgs universitet under 2000-talet.

När det gäller språkvetenskap, kan man tillägga att ovan nämnda forskarskola, liksom den av Riksbankens Jubileumsfond finansierade forskarskolan i engelska, tyska och franska, i någon mening kan sägas ha givit konstgjord andning åt den mer markanta språkvetenskapliga närvaron vid Stockholms universitet (liksom vid Linnéuniversitetet). Betydande ekonomiska fördelar för doktoranderna var förknippade med dessa forskarskolor och frågan är hur många av doktoranderna som skulle ha valt språkvetenskapliga ämnen om det inte varit för de fördelar som forskarskolorna erbjöd. Alla projekt medför fördelar för inblandade parter och det jag sagt gäller naturligtvis också de ovan nämnda projekten om samtals- och språkinlärningsforskning, vilka 
har utgjort konkurrenter till litterärt inriktade avhandlingsämnen. Detta är dock bara en hypotes, men det skulle vara av intresse att se närmare på vad deltagarna i forskarskolorna har ägnat sig åt för forskning efter disputationen. Mycket glädjande är hur som helst att många av dem som disputerade i forskarskolornas regi (ett imponerande antal, såväl i franska och spanska som i italienska och portugisiska) har fått tjänster vid svenska universitet och högskolor och har ombesörjt en betryggande återväxt av romanister vid våra lärosäten. En faktor som inte bör negligeras är att man i de tjänster som hittills utlysts i de romanska språken ofta av tradition har fört fram språkvetenskaplig meritering som viktig och avgörande för tillsättning av många lektorat och professurer.

\subsection{Gränsdragningar, skiljelinjer, definitioner och ämnesval}

Det kan vara värt att nämna att det från och till har förts en debatt om huruvida den litterära forskningen på språkinstitutionerna inte snarare borde bedrivas inom ramen för de litteraturvetenskapliga institutionerna och om den lingvistiskt inriktade forskningen i särspråken inte borde ha sin naturliga hemvist inom ramen för de allmänlingvistiska institutionerna. Detta kanske kan förefalla motiverat framför allt med tanke på att den teoretiska förankringen och forskningens specialisering generellt sett är tydligare och mer utvecklade på nämnda institutioner beroende på möjligheterna till tidig teoretisering på grundnivån tack vare avsaknaden av det för särspråksämnena mödosamma och tidskrävande färdighetsmomentet - i takt med de språkstuderandes försämrade förkunskaper tenderar färdighetsmomentet att i allt högre grad sätta sin prägel på grundutbildningen i särspråken, vilket ger mindre tid för utvecklande av ett vetenskapligt förhållningssätt (cf. Eriksson 2011). När det gäller Göteborgs universitet, kan man nog hävda att de litterära ämnen som varit föremål för avhandlingar i franska och spanska med åren har blivit teoretiskt och metodologiskt djärvare och innehållsligt mer djuplodande. Här har t.ex. den roll som biträdande och externa handledare kommit att spela sannolikt haft stor betydelse.

Det har också periodvis gått skarpa skiljelinjer och funnits - mer eller mindre uttalade - motsättningar mellan språk och litteratur på språkinstitutionerna, motsättningar som ibland haft en negativ inverkan på verksamheten vid flera lärosäten. Detta gäller i båda lägren (inte minst i Göteborg när det 
begav sig): traditionella språkvetare har ibland haft svårt att acceptera nya signaler och tendenser och litteraturvetarna har å sin sida ibland tyckt att språkvetarna ägnat sig åt "själlösa" studier av dubiöst humanistiskt värde. Det förefaller dock som om yngre generationer forskare har lättare att fördra och uppskatta varandras specialiseringar, att "gränsöverskridanden" blir allt vanligare och att litteraturvetare och språkvetare ser sig som komplementära inom ramen för både forskning och undervisning (cf. Larsson 2020).

Det finns emellertid, syns det mig, starka argument för att även fortsättningsvis låta språkämnena inrymma både språkvetenskap och litteraturvetenskap på forskarnivån: dels på grund av kopplingen mellan grund- och forskarnivå, som annars skulle riskera att i längden medföra en försämrad rekryteringssituation för forskarutbildningen, dels på grund av att det idag är vanligt med externa handledare med specialistkompetens på doktorandernas avhandlingsområden, något som ger goda möjligheter till ökad kvalitet och fördjupning. Överhuvudtaget har tvärvetenskapliga inslag och olika typer av samarbeten över institutions- och nationsgränser utvecklats explosionsartat under de senaste decennierna, inte minst tack vare internet och det påfallande stora utbudet av kongresser, symposier och workshops.

Ett problem värt att diskutera är hur man skall definiera och avgränsa det som man menar med ett litterärt ämne. Som nämnts, har de gränsdragningar mellan språk- och litteraturvetenskap som tidigare upprätthölls blivit otydligare samtidigt som det tillkommit nya discipliner utan förutbestämd hemvist endast inom en av språkämnenas domäner. Det är således svårt att ge en entydig definition av vad som avses med ett litterärt ämne. Som en illustration kan man nämna översättningsvetenskap, som inte sällan inbegriper både språkliga och litterära aspekter - och även kulturella sådana, t.ex. litteraturförmedling och dess implikationer på olika områden (cf. Cedergren \& Briens 2015).

Vad beträffar ämnesvalen för doktorsavhandlingar i romanska språk, beskriver franskan, efter en nästan sekellång period av praktiskt taget total språkvetenskaplig dominans, en snabb utveckling mot litterära ämnen under de senaste decennierna, medan spanskan redan på ett tidigt stadium av avhandlingsförfattande i detta språk uppvisar ett relativt fritt förhållningssätt i detta avseende, till stor del beroende på den spanska lärarkårens positiva inställning i fråga om ämnesvalets "frihet". Därav det starka inslaget av lit- 
terärt inriktade avhandlingar i spanska redan från tidigt 80-tal. Professorn i romanska språk, särskilt franska 1977-1988, Gunnar von Proschwitz, var däremot konservativ i så måtto att han inte ville se sina doktorander skriva avhandlingar om levande författare och deras verk, eller om författarskap med förankring i den fransktalande världen utanför Frankrikes gränser. Denna hans inställning påverkade i några fall doktorander att antingen välja mer accepterade ämnen eller att byta universitet. Han torde inte ha varit den ende handledare vars egna preferenser har fördröjt utvecklingen mot friare ämnesval.

Det litterära fokuset i avhandlingar, och även i examensarbeten på grundnivå, har gått från motstånd till acceptans inom många språk och på många lärosäten. Förutom motståndare till utvecklingen har det också funnits förgrundsfigurer som gått i bräschen för, eller åtminstone utan problem anammat, nya strömningar och intresseinriktningar. En sådan person var Alvar Ellegård, framsynt och dynamisk professor i engelsk språkvetenskap vid Göteborgs universitet 1962-1984. Han var på ett tidigt stadium angelägen om att ge utrymme åt litterära ämnen. I engelska fanns också under samma tid en professor i engelsk litteraturvetenskap, Erik Frykman (1967-1984), vilket givetvis också bidrog till att stärka litteraturens ställning (i samarbete med några drivande lektorer med uttalad litterär förankring).

\subsection{Språkundervisning på universitetets grundnivå}

Det förhåller sig självfallet så att tendenser som gör sig gällande på grundutbildningsnivåär av avgörande betydelse för hur utvecklingen kommer att gestalta sig på forskarutbildningsnivå. På samma sätt påverkas universitetens grundutbildning av tendenser som kan iakttas i den svenska skolan. På denna punkt kan man konstatera att det inom språkundervisningen på universitetets grundnivå och inom skolväsendet har funnits en parallell utveckling bort från ett studium med fokus på språklig korrekthet på detaljnivå (gäller både grammatik och vokabulär). Inom skolan har riktningen av naturliga skäl inte varit mot det litterära (med tanke på den begränsade språkfärdighetsnivån) men väl mot det kommunikativa, dvs. från form till innehåll. På universitetets grundnivå har riktningen varit mot de studerade verkens innehåll och deras "litterära budskap" i vid bemärkelse och i undervisningen är man där nu i allmänhet mer inriktad på "global" textförståelse och 
textanalys än på en detaljerad språklig analys. Ett tecken på detta är bl.a. att det tidigare omhuldade momentet version, dvs. översättning av textutdrag från målspråk till källspråk (dvs. svenska), nästan helt försvunnit som examinationsform och inte längre anses vara ett relevant sätt att närma sig en litterär text (utom inom översättarutbildningar).

Det bör dock påpekas att det språkliga studiet av de romanska språken på universitetets grundnivå fortfarande spelar en viktig roll beroende på att nybörjarstudenterna idag generellt sett har en betydligt lägre språklig ingångsnivå jämfört med tidigare och att tid därför måste ägnas åt att höja språkfärdighetsnivån. Den begränsade språkfärdigheten sätter ganska snäva ramar för den litteratur som man kan förvänta sig att studenterna klarar av att tillgodogöra sig under de första två terminernas studier. Det är därför nödvändigt att anslå ett betydande utrymme åt språkfärdighetsmomenten, dvs. grammatik, skriftliga övningar och vokabulärstudier, för att studenterna skall nå en språklig nivå som möjliggör ett mer avancerat litteraturstudium.

När det gäller val av kurslitteratur på universitetets grundnivå - som således sker inom vissa givna språkliga ramar med tanke på studenternas begränsade språkfärdighet - påverkar också de undervisande lärarnas tycke, smak och intressen valen på ett mer eller mindre tydligt sätt. Det torde inte vara ett försumbart faktum att de impulser som studenterna utsätts för på grundnivån får inflytande på deras senare val av ämne för examensarbeten (cf. Eriksson 2011) och, i de fall de går vidare till forskarstudier, sannolikt också på deras forskningsinriktning och avhandlingsämnen.

\subsection{Licentiatavhandlingarna vid Göteborgs universitet}

Man kan konstatera att ämnena "spretar" i de tidiga licentiatavhandlingarna (t.o.m. 1970-talet), som ofta utgjordes av studier fristående från de påföljande doktorsavhandlingarna. Det tycks också ha varit vanligare förr att de som skrev licentiatavhandlingar inte gick vidare till doktorandstudier. Även idag är licentiatavhandlingen efter ett uppehåll pånågra decennier ett vanligt förekommande inslag i forskarstudierna, men nu som ett steg på vägen mot doktorsavhandlingen - man har ju för övrigt på senare tid infört termen "licputation". Licentiatavhandlingen utgörs numera i allmänhet av en förstudie eller en delstudie till den kommande doktorsavhandlingen. 
Mellan 1891 och 1945 lades 18 licentiatavhandlingar i romanska språk fram vid Göteborgs högskola, men den första litterära licentiatavhandlingen såg dagens ljus först 1937 (La genèse d'un roman de Balzac; Louis Lambert. Édition critique avec une introduction). Äldre franska dominerar ämnesvalen fram till 1945 och det görs många vokabulärstudier (även patois och ortnamn). Såväl franska som italienska, spanska, portugisiska, provensalska och katalanska är representerade (och i några fall rör det sig om komparativa studier). Mellan 1946 och 1995 finner man 37 licentiatavhandlingar, men få litterära sådana - Saint-Exupéry, Balzac och mexikanen Mariano Azuela är några exempel på författare vars verk behandlas. Man kan notera ett ganska stort antal italienska licentiatavhandlingar under denna period, liksom under den föregående. Vokabulärstudier (dialekter och personnamn) är fortfarande vanliga, men ämnen med inriktning på modern fransk syntax är nu på frammarsch. "Nya" ämnen, som illustrerar licentiatavhandlingarnas friare förhållningssätt till ämnesval, är t.ex. reklamspråk (1967) och frankofon litteratur (1971).

Licentiatexamen avskaffades på 1970-talet men återinfördes i början av 1990-talet. De "nya" licentiatavhandlingarna är som nämnts i större utsträckning än tidigare förarbeten till de kommande doktorsavhandlingarna, och det är idag få studerande i förhållande till tidigare som avslutar sina forskarstudier i samband med licentiatexamen. Denna har främst blivit en etapp på vägen till doktorsexamen. Visserligen ger sedan några år tillbaka licentiatexamen på nytt behörighet att söka lektorat inom skolväsendet, men eftersom man samtidigt måste konstatera att lektoraten vid svenska gymnasier idag är ytterst få till antalet, så är det likväl ingen överdrift att säga att dagens licentiatavhandlingar endast i undantagsfall leder till förbättrade möjligheter på arbetsmarknaden. Viktiga faktorer för denna utveckling är naturligtvis också att dagens doktorandutbildningar är mer överblickbara än tidigare - fyra års studier med realistiska mål uppsatta -, att finansieringen via doktorandtjänster är tryggad under utbildningstiden och att handledningen är striktare organiserad och därmed oftare bättre fungerande än tidigare. Incitamenten att fortsätta sina forskarstudier efter licentiatexamen är numera mycket påtagliga och en doktorsexamen i ett romanskt språk ger också goda möjligheter till ett framtida yrkesliv inom akademin. 


\subsection{Doktorsavhandlingar vid}

\section{Göteborgs universitet mellan 1946 och 1995}

Mellan 1891 och 1945 - alltså drygt femtio år - lades det fram 6 doktorsavhandlingar i romanska språk vid Göteborgs högskola. Samtliga är språkvetenskapliga och behandlar olika grammatiska eller lexikaliska fenomen i den äldre franskan. Noteras kan att det även förekommer studier som behandlar språkliga företeelser i provensalskan.

Mellan 1946 och 1995 - nästa femtioårsperiod - har antalet doktorsavhandlingar i romanska språk vid samma lärosäte ökat väsentligt, nämligen till 34. Fortfarande dominerar de språkliga ämnena och äldre franska har fortfarande, framför allt i början av perioden, sin givna plats. Vokabulärstudier fortsätter att dra till sig doktorander, inte minst sådana med patois i fokus, liksom personnamnsstudier. För övrigt kan nämnas att den senaste doktorsavhandlingen med fornfranskt ämne vid Göteborgs universitet lades fram 1985, varefter de har lyst med sin frånvaro. De äldre språkskedenas efter hand försvagade ställning avspeglas också på grundnivån, där man inom utbildningarna i de romanska språken inte längre ägnar dessa perioder någon större uppmärksamhet.

När det gäller doktorsavhandlingarna mellan 1946 och 1995, konstaterar man också att synkroniska studier med modern syntax i fokus har etablerat sig. Och likaledes att litterära avhandlingar blir vanliga från och med början av 1980-talet och därefter stadigt ökar i antal, både i franska och spanska. Litterära avhandlingar i spanska ser dagens ljus från och med början av 1980-talet. I italienska följdes den första språkvetenskapliga avhandlingen från 1974 först 2005 av ytterligare en, och den första, och hittills enda, litterära italienska avhandlingen kom 2002 (senare publicerad på ett italienskt förlag). I motsats till spanskan, som har fått uppleva en mycket dynamisk utveckling i fråga om avhandlingar, har italienskan förlorat sin tidigare relativt starka ställning, vilken framför allt var tydlig på licentiatnivå, och det har alltså inte förekommit någon disputation i italienska sedan 2005. I detta sammanhang kan noteras att framför allt de tidiga professorerna i romanska språk ofta hade italienska som en andra specialitet och man kan inte utesluta att detta kan ha påverkat italienskans tidigare mer gynnsamma position bland de romanska språken vid Göteborgs universitet. 
Den första franska litterära doktorsavhandlingen kom 1953 och behandlar den franske författaren Pierre Loti, Evvasions et désespérances de Pierre Loti. Därefter är det ett hopp fram till 1983, då Eva Ahlstedt lade fram sin receptionsstudie La Pudeur en crise, som behandlar Marcel Prousts $A$ la Recherche du temps perdu. Gunnar von Proschwitz "1700-talsprojekt" resulterade i 6 avhandlingar mellan 1984 och 1987. En litterär avhandling, publicerad 1987, behandlar ansatserna till en fransk arbetarlitteratur under 1930-talet och rörelsens förgrundsfigur Henry Poulaille. Denna avhandling innebar ett slags trendbrott och markerar inledningen till en period av mer renodlat litteraturvetenskapligt avhandlingsförfattande i franska. Samtliga avhandlingar från denna period håller sig inom Frankrikes gränser, medan "la francophonie" lyser med sin frånvaro.

Den första spanska litterära avhandlingen kom, som ovan nämnts, 1983 och under de följande åren kommer regelbundet fler, samtliga med latinamerikansk litteratur som ämne och med en övergripande karaktär (den magiska chilenska muntliga berättelsen, berättartekniken hos Vargas Llosa, kortberättelsen i den uruguayanska litteraturen, den historiska romanen i Chile). Spanskan kommer starkt under denna period och när man ser till avhandlingsförfattarnas bakgrund, kan man i flera fall se förklaringar till att latinamerikanska ämnen dominerar. Som påpekats, har litteraturen från början haft en stark position inom ramen för de spanska avhandlingsämnena och fortsätter att ha det, även om de litterära ämnena inte är lika dominerande i spanska som de har blivit i franska vid Göteborgs universitet.

\subsection{Doktorsavhandlingar vid}

\section{Göteborgs universitet mellan 1996 och 2016}

Man kan säga att antalet doktorsavhandlingar i franska och spanska ökade explosionsartat vid Göteborgs universitet mellan 1996 och 2016 och att ämnesutbudet breddades väsentligt. De litterära ämnena tar nu överhanden i franska och har en solid position även i spanska. Gemensamt för båda språken är att det är svårt att se någon egentlig enhetlighet i de litterära ämnesvalen. Avhandlingsskribenternas personliga bakgrund och intressen spelar in och även i viss mån handledarnas. Doktoranderna förefaller hur som helst ha haft stor frihet i sina ämnesval. De språkvetenskapliga avhandlingarna i franska och spanska behandlar modern syntax eller vokabulär och för 
franskan gäller att flera av de språkvetenskapliga avhandlingarna tillkom inom ramen för Riksbankens Jubileumsfonds forskarskola (som var renodlat språkvetenskaplig).

Ämnesinriktningarna i de litterära doktorsavhandlingarna i romanska språk, både vid Göteborgs universitet och vid andra lärosäten, är högst varierande och det är svårt att se några tydliga trender eller att dra några generella slutsatser (cf. nedan). Ämnena ”spretar", skulle man kunna säga, vilket ju inte i sig behöver vara något negativt. Såväl enskilda litterära verk som specifika författarskap och litterära riktningar återfinns bland ämnena, liksom i viss utsträckning komparativa studier.

För franskans vidkommande blir det under denna period ganska vanligt med "francophonie"-inriktade ämnen: Belgien (litterärt fält), Marocko (maghrebinsk litteratur sedan 1945) och Algeriet (tematisk studie om Assia Djebar) finns representerade (cf. Cedergren \& Lindberg 2015; Cedergren 2015; Cedergren \& Lindberg 2017). Några ämnen med utgångspunkt i tidigare epoker finner man också, men flertalet behandlar olika franskspråkiga 1900-talsförfattare, t.ex. Marguerite Duras, Michel Butor och Michel Houellebecq. Spanskan uppvisar ett mindre tydligt brott med det språkliga och erbjuder ett mer varierat utbud. Gränsöverskridande och "tvärvetenskapliga" ämnen gör nu också sitt intåg i spanska, t.ex. språksociologi (språk och identitet) och språkdidaktik, vilket ger nya perspektiv och infallsvinklar.

\subsection{Stockholms universitet}

Det är naturligtvis av vitalt intresse att i en studie av detta slag göra jämförelser mellan de svenska lärosäten som erbjuder forskarutbildning i de romanska språken. Jag begränsar mig här till att i stora drag och kortfattat beskriva situationen vid Stockholms universitet med avseende på de doktorsavhandlingar i romanska språk som där lades fram under perioden 1969 fram till 2016. Här kan först konstateras att italienskan har en betydligt starkare position vid Stockholms universitet än vid Göteborgs universitet och att även portugisiska här förekommer som ett romanskt språk inom ramen för forskarutbildningen. Man kan generellt säga, tycks det mig, att de romanska språken idag har en starkare och solidare ställning i Stockholm än i Göteborg, något som också bekräftas av det faktum att "romansk lingvistik" 2010 erhöll status som "excellent forskningsmiljö" vid Stockholms 
universitet. Orsakerna till de romanska språkens framgångar som forskarutbildningsämne vid Stockholms universitet är flera. Bland annat finns de att söka i det faktum att detta lärosäte var värdhögskola för den av svenska staten finansierade forskarskolan i romanska språk FoRom (2001-2014) (cf. Engwall 2017). En viktig roll för den romanska forskarutbildningens vitalitet vid Stockholms universitet spelade också dess medverkan i den av Riksbankens Jubileumsfond finansierade forskarskolan i engelska, tyska och franska.

Forskarskolorna hade, som påpekats, språkvetenskaplig inriktning och de bidrog tvivelsutan till den jämnare fördelning mellan språk- och litteraturvetenskapliga ämnen som utmärker avhandlingarna i de romanska språken vid Stockholms universitet. Vid detta universitet har man också initierat flera större, externt finansierade forskningsprojekt, t.ex. i samtalsforskning, språkinlärningsforskning och talspråksforskning - discipliner med språkligt fokus alltså - som också har påverkat forskarutbildningens inriktning. Det tål att än en gång framhållas att de doktorander som antogs till forskarskolorna befann sig i ett mycket fördelaktigt läge: trygg finansiering, regelrätt utbildning i forskningsmetodik, handfast handledning, uppbyggnad av ett nätverk genom gemensamma seminarier och kollokvier och, inte minst, kontinuerlig uppföljning som fick till resultat att avhoppen var få och disputationerna många. Till yttermera visso kom många av dem som disputerade inom FoRom i åtnjutande av postdoc-tjänster inom ramen för forskarskolan, vilket möjliggjorde fortsatt meritering (cf. Engwall 2017).

För franskans del gäller att de litterära ämnena i doktorsavhandlingarna blir fler allteftersom tiden går, men de litterära ämnena dominerar inte i Stockholm och det finns under senare decennier inte samma tydliga utveckling mot litteratur som i Göteborg. Man konstaterar också att det i Stockholm på 2000-talet fortfarande skrivs avhandlingar med inriktning mot äldre franska, vilket, som ovan nämnts, inte är fallet i Göteborg. I Stockholm är modern tidningsprosa representerad inom den språkvetenskapliga forskningen, ett inslag som saknar motsvarighet i Göteborg. När det gäller avhandlingsämnen i franska med litterär inriktning vid Stockholms universitet, kan man säga att dessa, liksom vid Göteborgs universitet, "spretar" och att det är svårt att se några klara linjer. Handledarnas roll påverkar förstås även vid Stockholms universitet; så har t.ex. professor Gunnel Engwalls 
Strindbergforskning avsatt spår. "La francophonie" finns med bland ämnena, le Maghreb tilldrar sig intresse, liksom i Göteborg. Autobiografiska texter, genusperspektiv, reception, berättarteknik, litteraturhistoria, bildspråk och tematik utgör det breda spektrum som undersöks i avhandlingarna. Det rör sig dock sammantaget om relativt få litterära avhandlingar och ämnenas spännvidd är, som framgår, stor.

För spanskan gäller, liksom för franskan, att de litterära ämnena i doktorsavhandlingar blir fler allteftersom tiden går, men att de inte heller här dominerar. Spanskan, liksom franskan, italienskan och portugisiskan, var involverade i forskarskolan FoRom och i de ovan nämnda projekten, vilket naturligtvis fick en avgörande betydelse för fördelningen mellan språkvetenskap och litteraturvetenskap i avhandlingsämnena. Man kan också se att Latinamerika (i vid bemärkelse) har en stark närvaro i såväl språk- som litteraturvetenskapliga avhandlingar. När det gäller litterära avhandlingsämnen i spanska, kan man säga att dessa, liksom i franska och liksom vid Göteborgs universitet, uppvisar stor variation och att det även här är svårt att se några klara linjer. Bland de olika ämnena finner man fiktion, myt, social kritik, existentiella aspekter, identitet, tidsuppfattning. Det rör sig, liksom i franska, om relativt få avhandlingar, men med stor innehållslig bredd. Latinamerikansk litteratur är mycket närvarande i de litterära avhandlingarna, kan tilläggas.

I italienska producerades det under den aktuella tidsperioden betydligt färre avhandlingar än i spanska, men det rör sig ändå om 9. De litterära avhandlingarna överväger i antal, men även i italienska finns avhandlingar med fokus på samtals- och språkinlärningsforskning. Liksom i franska och spanska är spännvidden stor i fråga om ämnena för de litterära avhandlingarna; man kan tala om en "blandad kompott".

Stockholms universitet är det enda lärosäte som har frambringat doktorer i portugisiska och det har blivit lika många avhandlingar som i italienska, alltså totalt 9. Ett bra resultat, ovedersägligen. I portugisiska överväger de språkvetenskapliga avhandlingarna, vilket dels beror på ämnets medverkan i ovan nämnda forskarskola och olika projekt, dels sannolikt också på att de två professorerna som var aktuella fram till nyligen hade språkvetenskaplig specialisering. Brasiliansk portugisiska står i fokus på ett tydligt sätt, både 
i de språkvetenskapliga och de litterära avhandlingarna. Vad beträffar de litterära avhandlingarna, utgör de ämnesmässigt en föga homogen grupp.

\subsection{Avslutning}

Det är ett obestridligt faktum, vilket denna studie klart visar, att forskarutbildning och forskning i romanska språk vid Göteborgs universitet under de senaste fyra decennierna uppvisar en utveckling från språk till litteratur och att denna utveckling har accelererat ju närmare dagens situation vi har kommit. Från ett läge där den lingvistisk-filologiska inriktningen och det allmänromanska perspektivet var i princip allenarådande, befinner vi oss 2016 i en situation där det litteraturvetenskapliga studiet av de enskilda romanska språken till och med dominerar, både vad beträffar forskarutbildningen och den forskning som bedrivs inom ramen för tjänst.

Studien pekar på en rad faktorer som kan ha bidragit till att framkalla dagens situation, t.ex. litteraturens stärkta position inom grundutbildningen, ett kulturklimat präglat av ett ökat intresse för litterära frågor, en mer allmänt omfattad uppfattning av språkliga problem och frågeställningar som mindre "samhällstillvända" och mindre relevanta än litterära.

Vi har slutligen konstaterat att utvecklingen från språk till litteratur, vid en jämförelse med Göteborgs universitet, inte varit lika påtaglig vid Stockholms universitet, framför allt beroende på att den där i inte ringa grad har motverkats av den verksamhet som bedrivits inom ramen för den språkvetenskapliga forskarskolan FoRom och inom stora, externt finansierade språkvetenskapliga forskningsprojekt.

\subsection{Tillägg}

Sedan tillkomsten 2016 av ovanstående text har man kunnat notera att bilden av styrkeförhållandena mellan språk- och litteraturvetenskaplig forskning inom ämnet franska vid Göteborgs universitet delvis förändrats, detta till förmån för den språkvetenskapliga forskningen. Man kan säga att det nu (januari 2019) råder balans mellan ämnets båda forskningsinriktningar. Utjämningen är primärt en konsekvens av förändrade personalförhållanden men också en följd av ökad forskningsaktivitet inom ämnets språkvetenskapliga del, något som har resulterat i ett läge där några språkvetenskapligt inriktade docenter inom en snar framtid kan förmodas ansöka om befordran 
till professor. Detta måste ses som mycket positivt mot bakgrund av att den tidigare ledigförklarade professuren i fransk språkvetenskap slutligen, av ekonomiska skäl, kom att dras in under tillsättningsproceduren.

Man får också intryck av att språkvetenskapliga frågeställningar under de senaste åren har tillmätts ökad vikt i franskstudierna, detta dels som en effekt av det starkare inslaget av lärare och handledare med språkvetenskaplig forskningsspecialisering, dels på grund av att språkvetenskapliga kurser numera utgör ett obligatoriskt inslag $\mathrm{i}$ franskstudierna på grundnivå. Språkets starkare ställning i franskstudierna avspeglar sig inte minst i valet av uppsatsämnen.

Även vad beträffar spanskämnet råder idag större jämvikt mellan språk och litteratur med avseende på lärarkårens fördelning på ämnets båda forskningsinriktningar: ämnet har för närvarande fyra forskningsverksamma lärare inom vardera området. Tilläggas bör emellertid att spanskämnets enda nuvarande professor har litteraturvetenskaplig forskningsspecialisering. Men även spanskan har, efter en avbruten professorstillsättning inom språkvetenskap, hamnat i en trots allt positiv situation, med lärare som i en ganska nära framtid kan komma i fråga för befordran till professor.

\section{Bibliografi}

Carlsson, Lennart, 1976: L'étude des langues romanes depuis 1890. I: Faculty of Arts at Uppsala University. Linguistics and Philology. Uppsala University 500 years, 6. Uppsala: Acta Universitatis Upsaliensis. 89-98.

Cedergren, Mickaëlle, 2015: Littérature française, littérature francophone ? L'enseignement universitaire suédois à la recherche d'un nouveau paradigme. I: Cedergren, Mickaëlle \& Briens, Sylvain (red.), Médiations interculturelles entre la France et la Suède. Trajectoires et circulations de 1945 à nos jours. Stockholm: Stockholm University Press (Stockholm Studies in Romance Languages, 2). 79-98.

Cedergren, Mickaëlle \& Briens, Sylvain (red.), 2015: Médiations interculturelles entre la France et la Suède. Trajectoires et circulations de 1945 à nos jours. Stockholm: Stockholm University Press (Stockholm Studies in Romance Languages, 2).

Cedergren, Mickaëlle \& Lindberg, Ylva, 2015: Vers un renouvellement du canon de la littérature francophone. Les enjeux de l'enseignement universitaire en Suède. Revue de littérature comparée, 89:2, 231-243. 
Cedergren, Mickaëlle \& Lindberg, Ylva, 2017: La lecture de la littérature francophone à la lumière d'un contexte nordique. Réflexions sur la recherche universitaire actuelle en littérature. I: Grall, Catherine (red.), Le roman français vu de l'étranger. Paris: Classiques Garnier, 9. 201-224.

Engwall, Gunnel, 2017: Forskarskolor: Erfarenheter, synpunkter och möligheter. Föredrag i samband med konferensen Romanska språk i Sverige - tradition och förnyelse vid Göteborgs universitet 20-21 april 2017.

Eriksson, Olof, 2011: Vetenskaplighet, självständighet, färdighet. En utvärdering av examensarbeten $i$ de moderna spràken (engelska, franska, spanska, tyska) vid Institutionen för språk och litteratur, Linnéuniversitetet. Opublicerad rapport, 33 sidor. Växjö: Linnéuniversitetet.

Larsson, Björn, 2020: Romanska språk nyligen, nu och i framtiden. I: Romeborn, Andreas \& Bladh, Elisabeth (red.), Romanistiken i Sverige. Tradition och förnyelse. Göteborg: Acta Universitatis Gothoburgensis, Romanica Gothoburgensia. Kriterium. 145-172.

Lindberg, Bo \& Nilsson, Ingemar, 1996: Göteborgs universitets historia, 2 vol. Vol. I: På högskolans tid. Vol. II: Ett växande universitet. Göteborg: Rektorsämbetet, Göteborgs universitet.

Nilsson, Ingemar, 1996: Göteborgs universitet 1891-1995. Data över professorer, docenter, avhandlingar och befordringsärenden, 3 vol. Göteborg: Rektorsämbetet, Göteborgs universitet.

Sundell, Lars-Göran, 2013: Les débuts de la philologie romane à Uppsala. I: Norén, Coco, Jonasson, Kerstin, Nølke, Henning \& Svensson, Maria (red.), Modalité, évidentialité et autres friandises langagières. Mélanges offerts à Hans Kronning à l'occasion de ses soixante ans. Bern: Peter Lang. 311-325.

Sundell, Lars-Göran, 2015: Den begynnande romanska filologin i Sverige. I: Lindberg, Bo \& Cullhed, Eric (red.), Klassisk filologi i Sverige: reflektioner, riktningar, översättningar, öden. Stockholm: Kungl. Vitterhets Historie och Antikvitets Akademien (Konferenser, 89). 117-130.

Söhrman, Ingmar, 2013: Les langues romanes à Göteborg. I: Söhrman, Ingmar \& Vajta, Katharina (red.), La langue dans la littérature, la littérature dans la langue. Textes réunis en hommage à Eva Ahlstedt. Göteborg: Acta Universitatis Gothoburgensis (Romanica Gothoburgensia, 51). 405-421. 